\title{
KEDUDUKAN HUKUM PEMEGANG POLIS PADA PERUSAHAAN ASURANSI YANG DINYATAKAN PAILIT $^{*}$
}

\author{
Oleh: \\ Ida Ayu Agung Saraswati** \\ Marwanto*** \\ A.A Gede Agung Dharmakusuma ${ }^{* * * *}$ \\ Bagian Kekhususan Hukum Bisnis \\ Fakultas Hukum Universitas Udayana
}

\begin{abstract}
ABSTRAK
Dewasa ini asuransi merupakan salah satu hal pokok yang menjadi kebutuhan Masyarakat Indonesia untuk memproteksi diri dari risiko-risiko kerugian di masa yang akan datang, sehingga dibentuklah ketentuan yang mengatur tentang perlindungan Pemegang Polis yang diatur dalam Pasal 52 Ayat (1) Undang-Undang 40 Tahun 2014 yang mengatur bahwa jika Perusahaan Asuransi pailit atau dilikuidasi pihak Pemegang Polis/tertanggung dalam pembagian harta kekayaannya memiliki kedudukan hukum yang lebih tinggi dari pihak lainnya. Namun disatu sisi pada pengaturan Pasal 55 Ayat (1) Undang-Undang Nomor 37 Tahun 2004 tentang Kepailitan dan PKPU menjelaskan bahwa kreditur dengan hak jaminan dapat mengeksekusi haknya seolah-olah tidak terjadi kepailitan.

Sehingga jika suatu Perusahaan Asuransi dinyatakan pailit oleh Pengadilan Niaga Pemegang Polis yang berkedudukan hukum sebagai kreditur dengan hak istimewa dan kedudukan hukum kreditur dengan pemegang jaminan kebendaan tidak mendapatkan kepastian hukum dalam hal menerima pembagian harta pailit. Adapun rumusan masalah dari penelitian ini ialah bagaimana perlindungan hukum Pemegang Polis pada Perusahaan Asuransi yang dinyatakan pailit dan bagaimana akibat hukum pailitnya suatu Perusahaan Asuransi terhadap Pemegang Polis. Jenis penelitian yang
\end{abstract}

* Jurnal ini merupakan ringkasan skripsi.

** Ida Ayu Agung Saraswati merupakan penulis pertama dari jurnal ini.

*** Marwanto merupakan penulis kedua dari jurnal ini.

${ }^{* * * *}$ A.A Gede Agung Dharmakusuma merupakan penulis ketiga dari jurnal ini. 
digunakan dalam penelitian hukum ini adalah penelitian yuridis normatif. Pendekatan masalah yang digunakan dalam penelitian ini yaitu pendekatan perundang-undangan dan pendekatan analisis konsep hukum.

Tujuan dari penelitian ini ialah untuk memahami kedudukan hukum Pemegang Polis pada Perusahaan Asuransi yang dinyatakan pailit. Kedudukan hukum dari Pemegang Polis ialah sebagai kreditur preferen karena pihak Pemegang Polis adalah pihak yang berpiutang serta sifat dari piutangnya diistimewakan oleh Undang-Undang Perasuransian sehingga tingkatannya lebih tinggi daripada kreditor lainnya. Undang-Undang tentang Perasuransian tersebut bertujuan untuk melindungi hak-hak Pemegang Polis/tertanggung dalam menerima manfaat asuransi, tidak terkecuali jika Perusahaan Asuransi mengalami kepailitan, pihak Perusahaan Asuransi dalam hal ini harus tetap menunaikan kewajibannya untuk memberikan manfaat dari asuransi.

\title{
Kata Kunci: Kedudukan Hukum, Kepailitan, Kreditur, Kreditur Preferen, Pemegang Polis
}

\begin{abstract}
Now days insurance is one of the main things that the people of Indonesia need to protect themselves from the risks of future losses, so that there are provisions that regulate the law protection of policy holders regulated in Article 52 Section (1) Law Number 40 of 2014 concerning Insurance stipulates that if the Insurance Company is bankrupt or liquidated, the Policy Holder / insured person in the distribution of his assets has a higher legal position than the other party. However in the regulation of Article 55 Section (1) of Law Number 37 Year 2004 concearning Bankruptcy and Postponement of Debt Repayment Obligations explained that secured creditors can execute their rights as if there were no bankruptcy.

If Insurance Company is declared bankrupt by the Commercial Court, the policy holder with legal standing as preferred creditors and legal standing of the secured creditors does not obtain legal certainty in terms of receiving the distribution of bankrupt assets. Formulation problems of this study are, how policy holder's legal protection in bankrupt insurance company, and how law effect of the bankrupt insurance company against the policy holder. The type of this legal research is normative juridical research. The problem approach used in
\end{abstract}


this study are the statute approach and analytical and conceptual approach.

The purpose of this study is to determine the legal standing of the Policy Holder in Declared Bankrupt Insurance Company. The legal standing of the policy holder is as preferred creditors, because the policy holder is a party with credit and the characteristic of the receivables is privileged by the Insurance Law so the position of policy holder as preferred creditors that higher than the other creditors. The Insurance Law aims to protect the rights of policy holder/insured in receiving insurance benefits, not least if the Insurance Company experiences bankruptcy, the Insurance Company in this case must fulfill its obligations to provide benefits from insurance.

\section{Kew Words: Legal Standing, Bankruptcy, Creditors, Preferred Creditors, Policy Holder}

\section{PENDAHULUAN}

\section{$1.1 \quad$ Latar Belakang}

Di era globalisasi ini asuransi sudah dianggap sebagai kebutuhan pokok yang mana merupakan kebutuhan manusia akan rasa aman dan terlindungi terhadap kemungkinan-kemungkinan dari risiko kerugian di kemudian hari. Asuransi dapat didefinisikan sebagai transfer adil atas risiko suatu kerugian, dari satu entitas ke entitas lain dengan cara membagi risiko melalui pembayaran dalam sejumlah premi. ${ }^{1}$

Perusahaan Asuransi sebagai badan/lembaga pelimpahan risiko memberikan ruang untuk setiap orang melimpahkan kemungkinan-kemungkinan terjadinya risiko kerugian yang timbul kepada pihak lain. Dengan perannya Perusahaan Asuransi sebagai

${ }^{1}$ Sri Rejeki Hartono, 2001, Hukum Asuransi dan Perusahaan Asuransi, Sinar Grafika, Jakarta, h.1. 
lembaga pelimpahan risiko membuat pihak Perusahaan Asuransi berperan sebagai pihak Penanggung.

Pelimpahan risiko ini dapat dilakukan dengan cara melakukan perjanjian antara pihak tertanggung dengan penanggung. Subekti mendefinisikan asuransi adalah suatu perjanjian consensueel. Artinya ia dianggap telah terjadi manakala telah tercapai kata sepakat antara kedua pihak. Meskipun demikian, undang-undang memerintahkan dibuatnya suatu akte di bawah tangan yang dinamakan polis, dengan maksud untuk memudahkan pembuktian jika terjadi perselisihan. ${ }^{2}$ Perjanjian tersebut mempunyai tujuan bahwa pihak yang mempunyai kemungkinan menderita risiko kerugian (pihak tertanggung) melimpahkan kemungkinankemungkinan dari risiko kerugian yang terjadi kepada pihak lain yang bersedia membayar ganti rugi (pihak penanggung), dan akte tersebut berguna menjadi pembuktian untuk salah satunya prihal suatu Perusahaan Asuransi mengalami kepailitan.

Kepailitan merupakan suatu proses dimana seorang debitur mempunyai kesulitan keuangan untuk membayarkan utang, sehingga debitur dinyatakan pailit oleh Pengadilan Niaga dikarenakan debitur tersebut tidak dapat membayar utangnya. ${ }^{3}$ Kepailitan berdasarkan Pasal 1 angka 1 Undang-Undang Nomor 37 Tahun 2004 tentang Kepailitan dan PKPU dapat diartikan sebagai sita umum atas semua kekayaan debitor yang pengurusan dan pemberesannya dilakukan oleh kurator di bawah pengawasan Hakim Pengawas. Pailit diartikan sebagai suatu kondisi ketidakmampuan

2 Subekti, 2003, Pokok-Pokok Hukum Perdata, Intermasa, Jakarta, h. 219.

${ }^{3}$ Andy Hartanto, 2015, Hukum Jaminan dan Kepailitan: Hak Kreditor Separatis dalam Pembagian Hasil Penjualan Benda Jaminan Debitor Pailit, Laksbang Justitia, Surabaya, h.59. 
debitur dalam melakukan pelunasan terhadap utang-utang kreditornya. Sehingga kepailitanlah yang menjadi solusi bagi seorang debitor yang tidak mampu lagi untuk membayar utang-utang kepada kreditornya. ${ }^{4}$ Idealnya suatu hukum kepailitan merupakan hukum yang dapat memberikan perlindungan terhadap pihak kreditor maupun kepada pihak debitor. ${ }^{5}$

Konsep utang dalam hukum kepailitan sendiri sesungguhnya sangatlah menentukan, jika tidak ada utang maka esensi dari kepailitan sendiri tidaklah ada. Karena kepailitan merupakan suatu pranata hukum untuk melakukan pembagian harta kekayaan debitor guna untuk melunasi utang-utang-nya kepada kreditor-kreditor ${ }^{6}$. Dalam Undang-Undang Kepailitan mengatur berkenaan dengan penggolongan kreditor untuk pemberesan harta pailit, hal ini diatur untuk menghindari kerugian dari pihak debitor pailit. Serta seluruh harta kekayaan debitor pailit dikuasai curator di bawah pengawasan dari hakim pengawas. ${ }^{7}$

Berkenaan perihal utang dan piutang, kreditor maupun debitor memiliki kewajiban dan hak masing-masing yang didasarkan pada perjanjian yang telah pihak-pihak tersebut buat ataupun yang

${ }^{4}$ Kadek Sutrisna, I Ketut Markeling, "Kedudukan Utang Upah Pekerja Dalam Kepailitan”, Kertha Semaya, Vol. 06, No. 02, Maret, 2018, hlm. 03, ojs.unud.ac.id, URL : https://ojs.unud.ac.id/index.php/kerthasemaya/article/view/39602 diakses tanggal 19 Mei 2019 jam 22.01

${ }^{5}$ Munir Fuady, 2017, Hukum Pailit Dalam Teori dan Praktek, Cetakan VI, Citra Aditya Bakti, Bandung, h.2.

${ }^{6}$ M. Hadi Shubhan, 2008, Hukum Kepailitan, Prinsip, Norma, dan Praktik di Peradilan, Kencana Prenada Media Group, Jakarta, h. 34.

7 Gedalya Iryawan Kale, A. A. Gede Agung Dharmakusuma, "Syarat Kepailitan Sebagai Bentuk Perlindungan Hukum Debitor Dalam Undang Undang Nomor 37 Tahun 2004", Kertha Semaya, Vol. 06, No. 03, Mei, 2018, hlm. 07, ojs.unud.ac.id, URL : https://ojs.unud.ac.id/index.php/kerthasemaya/article/view/40730 diakses tanggal 19 Mei 2019 jam 22.15 
disebabkan oleh undang-undang. ${ }^{8}$ Berkenaan dengan hak Pemegang Polis/tertanggung, pemenuhan hak-hak tersebut diatur ketentuannya dalam Pasal 52 Ayat (1) Undang-Undang Nomor 40 Tahun 2014 tentang Perasuransian yang mengatur bahwa, 'Dalam hal Perusahaan Asuransi, Perusahaan Asuransi Syariah, Perusahaan Resuransi, atau Perusahaan Resuransi Syariah dipailitkan atau dilikuidasi, hak Pemegang Polis, Tertanggung, atau Peserta atas pembagian harta kekayaannya mempunyai kedudukan yang lebih tinggi daripada hak pihak lainnya.'

Namun jika dilihat pada ketentuan Pasal 55 Ayat (1) UndangUndang Nomor 37 Tahun 2004 tentang Kepailitan dan Penundaan Kewajiban Pembayaran Utang juga mengatur ketentuan bahwa, 'Dengan tetap memperhatikan ketentuan sebagaimana dimaksud dalam Pasal 56, Pasal 57, dan Pasal 58, setiap Kreditor pemegang gadai, jaminan fidusia, hak tanggungan, hipotek, atau hak agunan atas kebendaan lainnya, dapat mengeksekusi haknya seolah-olah tidak terjadi kepailitan.'

Melihat dari pasal-pasal tersebut, pada ketentuan Pasal 55 Ayat (1) Undang-Undang Kepailitan dan PKPU menjelaskan bahwa, setiap kreditor pemegang hak jaminan kebendaan diposisikan dalam kedudukan hukum yang lebih tinggi/didahulukan dalam menerima pembagian harta pailit daripada kreditur lainnya, karena dapat dilihat dari ketentuan pasal tersebut menggaris bawahi bahwa kreditur pemegang hak jaminan kebendaan dapat mengeksekusi haknya seolah-olah tidak terjadi kepailitan. Sedangkan pada Pasal 52 Ayat (1) Undang-Undang Perasuransian mengatur ketentuan bahwa,

\footnotetext{
${ }^{8}$ Gatot Supramono, 2013, Perjanjian Utang-Piutang, Prenadamedia Group, Jakarta, h. 10.
} 
kedudukan Pemegang Polis diposisikan dalam golongan kreditor dengan hak istimewa (preferen) yang tingkatannya lebih tinggi/didahulukan dalam menerima pembagian harta pailit daripada kreditur lainnya.

Berdasarkan ketentuan dari pasal-pasal tersebut dapat dilihat adanya konflik norma, sehingga jika terjadi kepailitan pada suatu Perusahaan Asuransi maka akan terjadinya ketidakpastian hukum oleh norma-norma tersebut.

Dengan demikian untuk menyelesaikan konflik norma tersebut digunakan 2 (dua) landasan teoritis yang diantaranya ialah teori perlindungan hukum yang merupakan pandangan dari Fitzgerald, Satijipto Raharjo, dan Philipus M. Hadjon serta teori kepastian hukum yang merupakan pandangan dari Gustav Radburch dan $\mathrm{J}$ Van Kan.

\subsection{Rumusan Masalah}

1. Bagaimana perlindungan hukum Pemegang Polis pada Perusahaan Asuransi yang dinyatakan pailit?

2. Bagaimana akibat hukum pailitnya suatu Perusahaan Asuransi terhadap Pemegang Polis?

\subsection{Tujuan Penulisan}

Tujuan dari penulisan ini yaitu untuk memahami kedudukan hukum Pemegang Polis pada Perusahaan Asuransi yang dinyatakan pailit.

\section{ISI MAKALAH}

\subsection{Metode Penelitian}

\subsubsection{Jenis Penelitian}

Jenis penelitian yang digunakan pada penelitian ini adalah penelitian hukum normatif. Sebagai penelitian hukum normatif 
merupakan penelitian kepustakaan yang datanya diperoleh dari mengkaji bahan-bahan pustaka. Penelitian ini mengacu pada norma-norma hukum yang didapat dalam putusan-putusan pengadilan, norma-norma hukum yang ada dalam masyarkat, maupun dalam peraturan perundang-undangan.

\subsubsection{Jenis Pendekatan}

Adapun pendekatan masalah yang digunakan dalam penelitian ini yaitu pendekatan perundang-undangan dan pendekatan analisis konsep hukum.

\subsubsection{Sumber Bahan Hukum}

Dalam penelitian ini menggunakan sumber bahan hukum primer berupa asas-asas hukum, kaidah-kaidah hukum, bahan hukum sekunder berupa buku-buku hukum, dan bahan hukum tersier berupa jurnal-jurnal hukum.

\subsubsection{Teknik Pengumpulan Bahan Hukum}

Dalam penelitian ini teknik dalam pengumpulan bahanbahan hukum yang digunakan ialah teknik studi kepustakaan yaitu dengan membaca, menelaah, serta mengklasifikasikan datadata dari peraturan perundang-undangan maupun literaturliteratur yang tentunya berkaitan dengan permasalahan.

\subsubsection{Teknik Analisis Bahan Hukum}

Teknik analisis bahan hukum yang digunakan dalam penelitian ini adalah teknik sistematisasi, teknik interprestasi, teknik deskripsi, dan teknik argumentasi.

\subsection{Hasil dan Pembahasan}

\subsubsection{Perlindungan Hukum Pemegang Polis Pada Perusahaan Asuransi yang Dinyatakan Pailit}


Dalam upaya melindungi kepentingan tertanggung, Pemegang Polis, ataupun peserta yang dalam hal terjadinya likuidasi dan pencabutan izin usaha terhadap suatu Perusahaan Asuransi, Undang-Undang Perasuransian sudah menjamin bahwa hak dari tertanggung, Pemegang Polis, maupun peserta mempunyai kedudukan hukum yang lebih tinggi daripada hak pihak-pihak lainnya, sebagaimana diatur pada Pasal 52 Undang-Undang Perasuransian.

Selain Pasal 52 Undang-Undang Perasuransian upaya dalam menjamin perlindungan Pemegang Polis juga diatur dalam Pasal 53 Ayat (1) yang menyatakan bahwa, 'Perusahaan Asuransi dan Perusahaan Asuransi Syariah wajib menjadi peserta program penjaminan polis'. Pada penjelasan Pasal 53 Ayat (1) Undang-Undang Perasuransian pun juga menjelaskan bahwa dibentuknya program penjaminan polis dimaksudkan untuk menjamin pengembalian sebagian atau seluruh hak Pemegang Polis, Tertanggung, atau Peserta dari Perusahaan Asuransi yang dicabut izin usahanya dan dilikuidasi. Program penjamin polis yang dilaksanakan melalui Undang-Undang Perasuransian diamanatkan pada Pasal 53 Ayat (4) Undang-Undang Perasuransian yang menyatakan bahwa, 'Undangundang sebagaimana dimaksud pada ayat (2) dibentuk paling lama 3 (tiga) tahun sejak Undang-Undang ini diundangkan. '9 Sehingga dapat dilihat dari ketentuan pasal-pasal tersebut bahwa Undang-Undang Perasuransian meningkatkan perlindungannya bagi pihak Pemegang Polis, tertanggung, maupun peserta.

${ }^{9}$ Rosiani Niti Pawitri, 2017, Kedudukan Dan Perlindungan Hukum Pemegang Polis Pada Perusahaan Asuransi Yang Pailit Berdasarkan Undang-Undang Nomor 40 Tahun 2014 Tentang Perasuransian, Vol XXIII, 1 April 2017 


\subsubsection{Akibat Hukum Dipailitkannya Perusahaan Asuransi Terhadap Pemegang Polis}

Para nasabah dan Perusahaan Asuransi mengikatkan diri mereka dalam suatu perjanjian asuransi. Perjanjian asuransi tersebut diwujudkan dalam bentuk polis asuransi sesuai dengan ketentuan Pasal 255 KUHD. Perikatan tersebut muncul dari adanya perjanjian asuransi yang mana perjanjian tersebut dilakukan oleh Pemegang Polis guna untuk mendapatkan perlindungan atau pengelolaan atas risiko bagi dirinya/tertanggung.

Kedudukan hukum Pemegang Polis menjadi kreditur jika Perusahaan Asuransi tidak dapat membayarkan hak dari pemegang polis berupa klaim asuransi, sehingga Perusahaan Asuransi wajib membayarkan utangnya kepada pihak pemegang polis. Berdasarkan ketentuan Pasal 1 angka 2 Undang-Undang Kepailitan dan PKPU mengatur bahwa, 'Kreditur adalah orang yang mempunyai piutang karena perjanjian atau Undang-Undang yang dapat ditagih di muka pengadilan.' Sehingga dengan tidak dibayarnya hak Pemegang Polis oleh Perusahaan Asuransi yang mana hak tersebut lahir dari perjanjian asuransi dalam bentuk polis yang merupakan bukti sempurna yang dapat ditagihkan dimuka pengadilan, walaupun dalam hal ini terdapat hal-hal yang tidak diatur secara tegas dalam perjanjian tersebut, namun dalam pelaksanaannya menurut sifat perjanjian diharuskan untuk tetap sesuai dengan kepatutan, kebiasaan, atau undang-undang, hal ini didasarkan pada Pasal 1339 KUHPerdata. 10

10 I Ketut Artadi, 2014, Anatomi Kontrak Berdasarkan Hukum Perjanjian, Udayana University Press, Denpasar, h.32. 
Kedudukan Pemegang Polis sebagai kreditor dikarenakan Pemegang Polis memiliki piutang atau hak yang belum dibayarkan oleh Perusahaan Asuransi, sehingga dalam hal ini Perusahaan Asuransi wajib memenuhi kewajibannya kepada pihak Pemegang Polis, agar Pemegang Polis dapat menerima manfaat dari asuransi. Berdasarkan Pasal 52 Ayat (2) yang menyatakan bahwa, 'Dalam hal Perusahaan Asuransi atau Perusahaan Resuransi dipailitkan atau dilikuidasi, Dana Asuransi harus digunakan terlebih dahulu untuk memenuhi kewajiban kepada Pemegang Polis, Tertanggung, atau pihak lain yang berhak atas manfaat asuransi.' Sehingga dalam hal ini kedudukan hukum dari Pemegang Polis yaitu sebagai kreditur dengan hak istimewa (preferen).

Pasal 1134 KUHPdt menggaris bawahi bahwa kreditur pemegang hak jaminan memiliki kedudukan hukum yang lebih tinggi/ didahulukan dari pada kreditur dengan hak istimewa terkecuali undang-undang menentukan sebaliknya. Dengan begitu pihak Pemegang Polis memiliki tingkatan yang lebih tinggi daripada pihak kreditur lainnya termasuk pihak kreditor pemegang hak jaminan (separatis) dalam hal pailitnya suatu Perusahaan Asuransi karena pihak Pemegang Polis adalah pihak yang berpiutang serta sifat piutangnya diistimewakan oleh Undang-Undang Perasuransian. Sehingga dengan demikian memberikan akibat hukum bahwa pihak Pemegang Polis lah yang diutamakan dalam menerima hak-haknya atas pembagian harta kekayaannya jika suatu Perusahaan Asuransi dinyatakan Pailit atau dilikuidasi daripada pihak-pihak lainnya.

\section{PENUTUP}

\subsection{Simpulan}


1. Perlindungan hukum terhadap Pemegang Polis pada Perusahaan Asuransi yang dinyatakan pailit dapat dilihat dari Undang-Undang Perasuransian yang telah mengatur adanya lembaga penjaminan polis yang mana tujuan dibentuknya program penjaminan polis ialah untuk menjamin pengembalian sebagian atau seluruh hak Pemegang Polis, tertanggung, ataupun peserta lain jika sewaktu-waktu Perusahaan Asuransi tersebut dicabut izinnya dan dilikuidasi. Sebelum dana penjaminan polis terealisasi Perusahaan Asuransi, Perusahaan Resuransi, Perusahaan Asuransi Syariah, dan Perusahaan Resuransi Syariah wajib membentuk dana jaminan yang sesuai dengan jumlah dan bentuk yang telah ditetapkan oleh OJK.

2. Akibat hukum dipailitkannya suatu Perusahaan Asuransi memberikan pihak Pemegang Polis hak untuk didahulukan untuk menerima hak-haknya atas pembagian harta kekayaannya daripada pihak-pihak lainnya, yang mana dikarenakan kedudukan hukum dari Pemegang Polis ialah sebagai kreditur dengan hak istimewa (preferen), karena Undang-Undang Perasuransian mengistimewakan Pemegang Polis dalam hal menerima pembagian harta pailit suatu Perusahaan Asuransi, terlebih lagi kedudukan hukum Pemegang Polis sebagai kreditur dengan hak istimewa/preferen dapat dilihat dari sifat piutangnya dan sifat hak didahulukannya.

\subsection{Saran}

1. Hendaknya pemerintah merealisasikan pembentukan lembaga penjaminan polis seperti yang telah diamanatkan Pasal 53 Ayat (1) Undang-Undang Nomor 40 Tahun 2014 tentang 
Perasuransian, mengingat sudah lebih dari 3 tahun sejak dikeluarkannya Undang-Undang Nomor 40 Tahun 2014 tentang Perasuransian lembaga penjaminan polis belum juga dibentuk (Pasal 53 Ayat (4) Undang-Undang Perasuransian), sehingga Pemerintah terlihat mengabaikan amanat dari Undang-Undang Perasuransian itu sendiri.

2. Hendaknya dalam pailit dan dilikuidasinya suatu Perusahaan Asuransi kurator memperhatikan hak Pemegang Polis dalam mendapatkan pembagian dari harta pailit Perusahaan Asuransi. Karena dibentuknya Undang-Undang Nomor 40 Tahun 2014 Perasuransian ialah salah satunya dengan menimbang, meningkatkan pelindungan bagi Pemegang Polis/tertanggung.

\section{DAFTAR PUSTAKA}

\section{BUKU}

Artadi, I Ketut, 2014, Anatomi Kontrak Berdasarkan Hukum Perjanjian, Udayana University Press, Denpasar.

Fuady, Munir, 2017, Hukum Pailit Dalam Teori dan Praktek, Cetakan VI, Citra Aditya Bakti, Bandung.

Hartanto, Andy, 2015, Hukum Jaminan dan Kepailitan Hak Kreditor Separatis dalam Pembagian Hasil Penjualan Benda Jaminan Debitor Pailit, Laksbang Justitia, Surabaya.

Hartono, Sri Rejeki, 2001, Hukum Asuransi dan Perusahaan Asuransi, Sinar Grafika, Jakarta.

Shubhan, M. Hadi , 2008, Hukum Kepailitan, Prinsip, Norma, dan Praktik di Peradilan, Kencana Prenada Media Group, Jakarta. 
Subekti, 2003, Pokok-Pokok Hukum Perdata, Intermasa, Jakarta.

Supramono, Gatot, 2013, Perjanjian Utang-Piutang, Prenadamedia Group, Jakarta.

\section{JURNAL}

Gedalya Iryawan Kale, A. A. Gede Agung Dharmakusuma, "Syarat Kepailitan Sebagai Bentuk Perlindungan Hukum Debitor Dalam Undang Undang Nomor 37 Tahun 2004", Kertha Semaya, Vol. 06, No. 03, Mei, 2018, hlm. 07, ojs.unud.ac.id, URL : https://ojs.unud.ac.id/index.php/kerthasemaya/article/view/ 40730 diakses tanggal 19 Mei 2019 jam 22.15

Kadek Sutrisna, I Ketut Markeling, "Kedudukan Utang Upah Pekerja Dalam Kepailitan", Kertha Semaya, Vol. 06, No. 02, Maret, 2018, hlm. 03, ojs.unud.ac.id, URL : https://ojs.unud.ac.id/index.php/kerthasemaya/article/view/ $\underline{39602}$ diakses tanggal 19 Mei 2019 jam 22.01

Rosiani Niti Pawitri, 2017, Kedudukan Dan Perlindungan Hukum Pemegang Polis Pada Perusahaan Asuransi Yang Pailit Berdasarkan Undang-Undang Nomor 40 Tahun 2014 Tentang Perasuransian, Vol XXIII, 1 April 2017.

\section{PERATURAN PERUNDANG-UNDANGAN}

Kitab Undang-Undang Hukum Perdata (Burgerlijk Wetboek) Terjemahan Soedharyo Soimin, 1999, Sinar Grafika, Jakarta.

Indonesia, Undang-Undang Nomor 37 Tahun 2004 Tentang Kepailitan dan Penundaan Kewajiban Pembayaran Utang, Lembaran Negara Republik Indonesia Tahun 2004 Nomor 131, Tambahan Lembaran Negara Republik Indonesia Nomor 4484.

Indonesia, Undang-Undang Nomor 40 Tahun 2014 Tentang Perasuransian, Lembaran Negara Republik Indonesia Tahun 2014 Nomor 337, Tambahan Lembaran Negara Republik Indonesia Nomor 5618. 